\title{
STRATEGI RETORIKA PEMBAWA ACARA \\ DALAM MATA NAJWA DI TRANS7
}

\author{
Imaz Nafiza \\ e-mail: Imaznafiza15@gmail.com \\ Prodi Tadris Bahasa Indonesia \\ IAI Darussalam Blokagung Banyuwangi
}

\begin{abstract}
Abstrak
Penelitian ini bertujuan untuk menginterpretasikan fungsi bentuk retorika verbal dan nonverbal pembawa acara dalam Mata Najwa di Trans7 sebagai strategi retorika. Rancangan dan jenis penelitian ini menggunakan deskriptif kualitatif. Penelitian dilakukan secara komprehensif yang mengacu pada analisis bentuk retorika verbal dan nonverbal. Teknik pengumpulan data menggunakan teknik rekam, teknik simak, dan teknik catat. Sedangkan analisis data dalam penelitian ini mengklasifikasikan data dan mengelompokkan data. Untuk menguji keabsahan data maka peneliti menggunakan beberapa tahapan yaitu uji kredibilitas, pengujian transferability, pengujian depenability, pengujian konfirmability.

Hasil dari penelitian ini ditemukannya penggunaan retorika verbal (diksi dan gaya bahasa) dan nonverbal (bahasa tubuh) dari tuturan Najwa Shihab banyak mengandung unsur persuasif. Dari unsur persuasif tersebut digunakan sebagai strategi pembawa acara dalam Mata Najwa di Trans7.

Berdasarkan hasil dan pembahasan retorika verbal dan nonverbal dalam acara Mata Najwa di Trans7, maka diperoleh berbagai elemen verba dipilih yang berfungsi untuk melancarkan proses strategi pembawa acara dalam memengaruhi pendengar. Oleh karena itu, sebuah seni didalam berkomuikasi mutlak sangat diperlukan seorang pembawa acara dalam meyampaikan pesan melalui retorika bentuk tuturan verbal dan retorika tuturan bentuk nonverbal.
\end{abstract}

Kata Kunci : strategi retorika, retorika verbal, retorika nonverbal.

\begin{abstract}
This study aims to interpret the function of verbal and nonverbal rhetorical forms of presenters in Mata Najwa on Trans7 as a rhetorical strategy. The design and type of this research used descriptive qualitative. The research was conducted comprehensively which refers to the analysis of verbal and nonverbal rhetorical forms. Data collection techniques used recording techniques, listening techniques, and note-taking techniques. Meanwhile, the data analysis in this study was to classify the data and classify the data. To test the validity of the data, the researchers used several stages, namely credibility testing, transferability testing, depenability testing, and confirmability testing.
\end{abstract}


The results of this study found that the use of verbal (diction and style) and nonverbal (body language) rhetoric from Najwa Shihab's speech contained many persuasive elements. From the persuasive element, it was used as a strategy for the presenter in Mata Najwa on Trans7.

Based on the results and discussion of verbal and nonverbal rhetoric in the Mata Najwa program on Trans7, various verb elements were selected which functioned to expedite the process of the presenter's strategy in influencing listeners. Therefore, an art in communicating is absolutely necessary for a presenter in conveying messages through the rhetoric of verbal forms of speech and rhetoric of speech in nonverbal forms.

Keywords: rhetorical strategy, verbal rhetoric, nonverbal rhetoric.

\section{A. Pendahuluan}

Berbicara merupakan salah satu aspek keterampilan berbahasa yang bersifat produktif artinya suatu kemampuan yang sangat berguna bagi kehidupan untuk menunjang dalam suatu pekerjaan atau aktivitas sehari-hari. Keterampilan berbicara itu sangat penting bagi seseorang karena melalui keterampilan ini, seseorang dapat dengan mudah dalam menyampaikan gagasan, pikirannya sehingga gagasan-gagasan yang ada di dalam pikiran orang tersebut dapat di pahami oleh orang lain.

Retorika memiliki hubungan yang erat dengan berbicara, sebab berbicara menjadi titik tolak retorika. Manusia dalam berbicara yang ideal terbentuk dalam wujud ujaran yang lancer sampai ujaran tersebut tersampaikan dengan baik kepada mitra tutur (Manshur, 2021:34). Seorang penutur saat berkomunikasi, pada dasarnya tidak seluruh ujarannya direncanakan.Namun, .Penutur saat berkomunikasi, pada dasarnya tidak seluruh ujarannya direncanakan. Oleh karena itu, retorika sangatlah penting dalam berbicara, dikarenakan seseorang itu tidak cukup hanya mempunyai pengetahuan bahasa saja, tetapi juga harus memiliki kepandaian dan keterampilan dalam mengungkapkan isi pikiran secara tepat, jelas, dan meyakinkan.

Istilah retorika dapat ditemukan dalam bahasa Inggris dengan kata rethoric berarti kepandaian dalam berbicara ataupun berpidato. Dalam hal ini tentu, berbicara di depan khalayak umum diperlukan keterampilan berbahasa yang baik, jelas, penampilan yang menarik serta keefektifan dalam menyampaikan pesan kepada pendengar. Mardhiyah (2015: 4) mengatakan, "Retorika adalah 
sebuah ilmu yang mengajarkan tentang bagaimana cara berbicara di depan umum (public speaking)".

Komunikasi yang dilakukan dalam retorika tidak hanya menginformasikan suatu tujuan tertentu, melainkan bagaimana cara memenangkan opini dan memengaruhi dari lawan bicara (khalayak umum). "Retorika mempersoalkan tentang mencari suatu kebenaran dengan dialog sebagai tekniknya, karena di dalam dialog kebenaran itu didapatkan dengan sendirinya" (Iskandar, 2010: 3).

Seni didalam berbicara akan sangat membantu seseorang untuk menjadi pembicara yang sukses serta mampu memperlihatkan kekuatan gaya bahasanya dalam membujuk masyarakat dengan teknik persuasinya, dan menarik simpatik publik (Asmara, 2016: 380). Hal ini tentu membutuhkan penguasaan teknik dalam berbicara bukan hanya baik, tetapi juga menarik, serta memberikan kesan yang mendalam bagi pendengar.

Dalam buku Rhetorica, (Terjemahan W. Rhys Roberts, 2018: 18) menurut Aristoteles mengatakan ada tiga syarat yang harus dipenuhi dalam mengadakan persuasi yaitu watak, kredibilitas, pembicara, serta kemampuan pembicara untuk mengendalikan emosi para audiens, bukti atau fakta-fakta untuk membuktikan suatu kebenaran itu sangat diperlukan. Menurut Rahkmat dalam Ayu Linda Wulandari (2018: 142) mengatakan bahwa jenis-jenis strategi pembawa acara meliputi: teknik persuasi, menetapkan daya tarik motif, pencitraan, dan isi pesan persuasif.

Pembawa acara harus memiliki beberapa keterampilan yaitu keterampilan berbicara serta memandu sebuah acara menjadi lebih baik, menarik perhatian hadirin untuk terlibat dalam acara itu. Jika pembawa acara kurang dalam menguasai panggung maka jalannya acara akan menjadi hambar, kurang berkesan dan mengecawakan. Sebaliknya jika pembawa acara pandai dalam menguasai panggung dan menghibur hadirin tentu sebuah acara menjadi lancar dan menyenangkan.

Seorang pembawa acara merupakan orang yang memiliki tanggung jawab penuh dan peranan penting dalam kelangsungan sebuah acara. Dikatakan penting karena seorang pembawa acara kerap menjadi ruh atau kekuatan dalam sebuah acara, adakalanya seorang pembawa acara yang baik, adalah yang bisa 
menumbuhkan kesan mendalam pada pendengar, melalui cara ia memandu acara. Berbicara di depan umum tidak begitu sulit juga tidak begitu mudah. Dikatakan tidak begitu sulit, karena memang setiap hari kita berbicara, namun tidak begitu mudah karena tidak semua orang berani untuk melakukannya.

Dalam sebuah acara seorang pembawa acara yang dipandunya membutuhkan keterampilan tersebut, sekaligus karena disamping kata-katanya yang perlu diperhatikan, gerak tubuhnya di atas panggung merupakan bagian yang menjadi sorotan pemirsa. Salah satu gelar wicara yang menjadi perhatian peneliti saat ini adalah Mata Najwa. Acara ini dipandu oleh pembawa acara senior Najwa Shihab yang ditayangkan distasiun Trans7. Najwa Shihab merupakan salah satu pembawa acara yang mempunyai karakter tersendiri dalam memandu acaranya dan memiliki kredibilitas yang tinggi. Terbukti darah dari kelahiran Makassar, 16 September 1977 ini mendapat banyak penghargaan salah satunya, yaitu dua besar jajaran perempuan yang paling dikagumi di Indonesia 2019 versi survei online dari YouGOv (Lembaga survei Indenpenden yang berkantor pusat di Inggris). Selain itu menurut Fali, Thahar dan Tressyalina (2018: 116) masyarakat telah mengenal Najwa Shihab sebagai sosok yang cerdas dan kritis. Pendapat tersebut didukung oleh Syaifudin (2013: 2 dalam Falia, Thahar dan Tressyalina, 2018: 116) yang mengatakan bahwa Mata Najwa merupakan tontonan yang layak diperhitungkan, hal tersebut disebutkan Mata Najwa memuat nilai edukatif yang tinggi.

Najwa Shihab merupakan sosok tokoh jurnalis senior yang memiliki strategi retorika yang sangat memukau dalam menyampaikan pesan, sehingga kerap mendatangkan berbagai narasumber di dunia politik ataupun sosial. Bahkan tidak jarang dengan strategi retorika yang dimiliki oleh Najwa Shihab mampu memancing narasumber untuk mengungkapkan berbagai informasi baru yang belum diketahui oleh publik. Hal itu tentu merupakan tujuan dari adanya sebuah retorika di dalam menyampaikan pesan yaitu untuk memengaruhi dan merayu publik dalam rangka membentuk opini publik.

Najwa Shihab kerap membuat narasumbernya tidak bisa berkutik untuk menghindar karena jebakan yang sering diungkapkan dengan gaya bahasanya, sehingga tidak diragukan lagi retorika yang dimiliki Najwa Shihab, banyak 
mengandung unsur persuasif (membujuk) yang tinggi, seperti bahasa lisan, penggunaan suara, serta berirama dalam menyampaikan pesan. Hal ini tentu tidak mengherankan karena Najwa Shihab merupakan seorang tokoh jurnalis yang aktif didunia pers.

Kemampuan retorika seorang Najwa Shihab merupakan suatu wujud dari keterampilan berbicara yang sangat memukau dan mampu menggunakan strategi retorika yang begitu menarik dengan teknik persuasi. Teknik persuasi sangat diperlukan dalam memengaruhi atau mengajak pendengar agar mau mengikuti apa yang disampaikan oleh pembawa acara. Melalui acara Mata Najwa di Trans 7 yang ditayangkan setiap malam Rabu, pukul 20.00 WIB merupakan salah satu tayangan televisi yang menyajikan berbagai informasi terbaru di indonesia yaitu mengenai tema wabah virus corona yang sedang hangat diperbincangkan, dengan mengundang berbagai narasumber yang mempunyai pengaruh penting dalam topik yang nantinya akan dibahas dan diulas lebih mendalam. Program talk show "Mata Najwa" tentu mempunyai pesan dan kesan yang sangat menarik untuk ditonton, sebab Najwa Shihab selaku pembawa acara dituntut harus mampu memperoleh informasi yang jelas dan akurat dari narasumber yang dihadirkan terkait dengan topik permasalahan yang akan dibahas.

Oleh karena itu, dalam acara tersebut Najwa Shihab terlihat lebih memfokuskan dirinya untuk bertanya kepada narasumber tentang segala hal berkaitan dengan topik yang dibahas pada saat itu. Ketika melakukan kegiatan bertanya itulah, Najwa Shihab menggunakan srtategi retorika agar informasi yang diperoleh jelas dan akurat. Salah satu strategi yang digunakan Najwa Shihab yaitu berkaitan dengan pertanyaan-pertayaan yang diberikan Najwa Shihab kepada narasumber. Selain sarana untuk memperoleh informasi pertanyaan menjadi hal yang sangat penting didalam sebuah perbincangan, karena pertanyaan dapat dijadikan sebagai rangsangan untuk mengaktifkan permasalahan yang akan dibahas.

\section{B. Metode Penelitian}

Menurut Hikmah (2021:62) pendekatan kualitatif digunakan untuk memperoleh gambaran yang jelas, objektif, sistematis, dan cermat mengenai 
fakta-fakta aktual dari sifat populasi.Penelitian deskriptif kualitatif adalah prosedur penelitian yang menghasilkan data deskripsi berupa kata-kata tertulis dan lisan dari orang-orang dan perilaku yang dapat diamati.Jenis penelitian ini adalah dengan menggunakan penelitian kualitatif. Penelitian kualitatif adalah penelitian yang bersifat sementara, tentatif, dan akan berkembang atau berganti setelah peneliti berada di lapangan (Sugiyono, 2015: 283). Peneliti mengambil metode kualitatif ini untuk mengetahui bagaimana penggunaan materi kebahasaan yang berupa retorika dalam bentuk verbal dan nonverbal dalam Strategi Retorika Pembawa Acara Dalam Mata Najwa Di Trans7.

Data yang diambil dalam penelitian ini berupa tuturan retorika bentuk verbal (diksi atau pemilihan kata, gaya bahasa), tuturan retorika bentuk nonverbal (bahasa tubuh, ekspresi wajah, isyarat, gerakan, sentuhan, jarak, kontak mata dan penampilan fisik), serta kaitan bentuk verbal dan nonverbal dengan strategi pembawa acara dalam Mata Najwa di Trans7.

Penelitian ini menggunakan teknik pengumpulan data menggunakan metode penyimakan video dan pencatatan. Metode pencatatan dapat dilakukan terhadap sumber data. Sumber data yang terdapat didalam penelitian ini yaitu berupa tuturan yang ada dalam gelar wicara Mata Najwa di Trans7 yang ditayangkan setiap hari Rabu pukul 20.00 WIB, dengan informasi terbaru yaitu tentang wabah virus corona di Indonesia dengan mengundang berbagai narasumber dari bidang kesehatan, sosial masyarakat. Jenis data dalam penelitian ini, yaitu dalam bentuk kata-kata dan tindakan serta sumber yang tertulis. Sedangkan sumber data yang diambil dalam penelitian ini disesuaikan dengan konsep menurut Lofland, (dalam Moleong 2012: 157) bahwa sumber data utama di dalam penelitian kualitatif yaitu berupa kata-kata, tindakan, dan selebihnya berupa data tambahan seperti dokumen dan lain-lain

Jenis data dalam penelitian ini, yaitu dalam bentuk kata-kata dan tindakan serta sumber yang tertulis. Sedangkan sumber data yang diambil dalam penelitian ini disesuaikan dengan konsep menurut Lofland, (dalam Moleong 2012: 157) bahwa sumber data utama di dalam penelitian kualitatif yaitu berupa 
kata-kata, tindakan, dan selebihnya berupa data tambahan seperti dokumen dan lain-lain.

Teknik pengumpulan data yang digunakan dalam penelitian ini ada tiga macam yaitu teknik rekam dalam penelitian ini digunakan untuk pengumpulan data dengan menggunakan sarana dari situs internet yakni https://www.narasi.tv. Kemudian dengan teknik rekam diperoleh data tuturan retorika bentuk verbal (diksi dan gaya bahasa) dan tuturan retorika bentuk nonverbal yaitu bahasa tubuh, gerakan mata, sentuhan, isyarat, ekspresi wajah, penampilan fisik, serta kaitan retorika verbal dan nonverbal dalam strategi pembawa acara dengan teknik persuasi dalam acara Mata Najwa di Trans7. Selanjutnya teknik simak, setelah didapatkan hasil rekaman yang diunduh dari laman daring youtube https://www.narasi.tv gelar wicara Mata Najwa di Trans7, maka penelitian terhadap data dilakukan yaitu dengan menggunakan teknik simak. Teknik simak dilakukan dengan cara menyimak bentuk retorika verbal dan retorika nonverbal serta kaitan retorika verbal dan nonverbal dalam strategi pembawa acara dalam acara Mata Najwa di Trans7 yaitu secara berulang-ulang. Teknik catat, Setelah melakukan teknik simak secara berulang-ulang kemudian data tersebut dicatat atau ditranskripkan keseluruhan bentuk retorika verbal dan nonverbal tuturan Najwa Shihab dalam acara Mata Najwa di Trans7. Dari hasil catatan keseluruhan bentuk-bentuk retorika verbal dan nonverbal dalam acara Mata Najwa di Trans7 merupakan data utuh, yang nantinya digunakan untuk dianalisis serta dijadikan sebagai strategi pembawa acara dengan teknik persuasi.

Adapun teknik analisis data yang peneliti gunakan dalam penelitian ini menggunakan metode deskriptif kualitatif yaitu:

1. Pengamatan data dilakukan terhadap pemakaian retorika verbal dan nonverbal Najwa Shihab sebagai pembawa acara Mata Najwa di Trans7 yang telah terkumpul dalam tabel pengumpul data. Pengamatan dilakukan bertujuan untuk meneliti kembali keabsahan data.

2. Pengkodean yang digunakan dengan maksud untuk memperjelas identitas dari masing-masing data.

Kode: 
T1-DDen/1 berarti Talkshow pertama (T1), mengandung diksi denotatif (DDen) terdapat pada part pertama (1) begitu juga sampai part ke tujuh.

T1-DKon/1 berarti Talkshow pertama (TI), mengandung diksi konotatif (DKon) terdapat pada part pertama (1) begitu juga sampai part ke tujuh.

T1-GRet/1 berarti Talkshow pertama (T1), mengandung gaya bahasa retoris (GRet) terdapat pada part pertama (1) begitu juga sampai part ke tujuh.

T1-GHip/1 berarti Talkshow pertama (T1), mengandung gaya bahasa hiperbola (GHip) terdapat pada part pertama (1) begitu juga sampai part ke tujuh.

T1-GPer/1 berarti Talkshow pertama (T1), mengandung gaya bahasa personifikasi (GPer) terdapat pada part pertama (1) begitu juga sampai part ke tujuh.

T3-GKha/5 berarti Talkshow ketiga (T3), mengandung gaya bahasa khas Najwa Shihab (Gkha) terdapat pada part kelima (5).

3. Pengklasifikasian data-data yang telah terkumpul, diklasifikasikan dalam kategori dari masing-masing data yaitu menurut jenis diksi dan gaya bahasa.

4. Interpretasi melalui tahap pengklasifikasian data yaitu data-data yang sudah terkumpul dikelompokkan menurut kategori masing-masing data. Data yang sudah dikelompokkan, selanjutnya diinterpretasikan mengenai maksud dan tujuan penggunaan data dalam acara Mata Najwa di Trans7.

5. Simpulan dilakukan setelah tahap interpretasi, data yang sudah diperoleh interpretasinya disimpulkan dengan memaparkan setiap dari jenis retorika dan strategi pembawa acara yang digunakan pembawa acara dalam acara Mata Najwa di Trans7.

Instrumen penelitian dilakukan oleh peneliti sendiri yang didukung dengan alat pengumpul datanya berupa tuturan retorika bentuk verbal dan nonverbal Najwa Shihab yang peneliti dapatkan dari video di situs Mata Najwa di youtube.

\section{Hasil Dan Pembahasan}

Sebagaimana dengan tujuan dari penelitian ini diklasifikasikan berdasarkan pemakaian retorika verbal dan nonverbal Pembawa Acara Mata Najwa Di Trans7 sebagai retorika.

\section{Strategi Retorika Verbal}


Tuturan-tuturan yang digunakan olehNajwa Shihab dalam acara Mata Najwa di Trans7 menunjukkan bahwa pemakaian retorika verbal penggunaan diksi dapat berfungsi untuk mengungkapkan gagasan secara verbal dalam memberikan informasi kepada pendengar. Interpretasi dari diksi denotatif dapat menggambarkan suatu informasi kepada pendengar dengan kata-kata sehingga menimbulkan suatu ide atau gagasan dalam setiap kata atau pesan yang disampaikan Najwa Shihab mampu dalam mengendalikan emosi pemirsa, serta menarik perhatian dari setiap episode yang dibawanya dalam acara Mata Najwa di Trans7. Berikut berikut ini pemakaian kata yang bermakna denotatif dan interpretasinya terdapat pada data:

(1) Sayang sekali kita seperti tidak siap menerima kepanikan malah cepat merajalela. (T1-DDen/1)

Pada data 1 terdapat kata kepanikan dikatakan kata yang bermakna denotatif karena berkaitan dengan makna yang sebenarnya, kata kepanikan memiliki arti khawatir atau takut terjadi sesuatu. Berdasarkan pada konteks kalimat “ Sayang sekali kita seperti tidak siap menerima kepanikan malah cepat merajalela " pada kalimat tersebut menggambarkan tentang kekhawatiran yang selalu muncul dengan adanya jumlah pasien positif corona semakin bertambah.

Selanjutnya, interpretasi diksi konotatif yang digunakan Najwa Shihab berfungsi membangun ide atau gagasan pendengar. Pemakaian diksi konotatif serta interpretasinya dapat ditemukan pada data 22.

(22) Pandemi jadi batu uji efektif dan efisiensinya negara cermin birokasi yang lapuk atau bertenaga. (T1-DKon/1)

Pada data di atas terdapat kata batu. Kata batu dengan melihat makna sebenarnya merupakan sebuah benda yang keras ada yang berbentuk lingkaran. Namun kata batu memiliki makna ganda atau dinamakan kata konotatif. Kata batu yang digunakan Najwa Shihab pada konteks kalimat di atas bukan batu benda keras berbentuk lingkaran melainkan kata batu berarti benda. Berdasarkan pada kalimat di atas bahwa Najwa Shihab menggunkan kata batu untuk mendeskripsikan pandemi akan menjadi benda percobaan. 
Selain dari menggunakan diksi atau pilihan kata, Najwa Shihab juga menggunakan gaya bahasa yang bertujuan untuk mengungkapkan gagasan atau pikirannya guna memperoleh informasi dari narasumber. Gaya bahasa yang digunakan Najwa Shihab jenis gaya bahasa berdasarkan langsung tidaknya makna yaitu dibedakan menjadi dua yaitu gaya bahasa retoris dan gaya bahasa kiasan.

Berikut ini akan diuraikan gaya bahasa yang digunakan Najwa Shihab dalam acara Mata Najwa di Trans7.

(22) Sudah dua bulan lebih corona mengancam dunia tak ada alasan bagi pemerintah terbata-bata. (T1-GPer/1)

Pada ada 22 menunjukkan gaya bahasa personifikasi yang ditunjukkan pada kalimat Sudah dua bulan lebih corona mengancam dunia tak ada alasan bagi pemerintah terbata-bata. Kata mengancam pada kalimat di atas merupakan gaya bahasa personifikasi mengacu pada proses yang menerangkan tindakan. Najwa Shihab menggunakan kata tersebut untuk mendeskripsikan bahwa tidak ada lagi alasan bagi pemerintah menghindar kini virus corona sudah mengancam indonesia bahkan negara.

(23) Kabar yang tidak diinginkan itu akhirnya tiba, virus corona baru telah masuk ke Indonesia, sayang sekali kita seperti tidak siap menerima kepanikan malah dengan cepat merajalela, kelangkaan alat kesehatan, pejabat ngomong serampangan, identitas pasien diumbar sembarangan, padahal corona bukan penyakit yang tak tersembuhkan selama penanganan dengan sebaik-baiknya dilakukan, mengapa respon kita tampak tergesa-gesa, apakah kita benar-benar siap menghadapi corona. (T1-GRet/7)

Pada data 23 menunjukkan penggunaan gaya bahasa aliterasi dan asonansi. Gaya bahasa aliterasi ditunjukkan pada pengulangan konsonan yang sama yakni terdapat pada kata kesehatan dan serampangan, selain itu juga terdapat pada kalimat tujuh yaitu sembarangan, dan dilakukan terdapat pada kalimat ke delapan. Sedangkan gaya bahasa asonansi merupakan pengulangan bunyi vokal yang sama sesuai konteks pada kalimat pertama , kedua, ketiga yakni ka ta tiba, indonesia, cepat merajalela. Kedua gaya bahasa di atas merupakan gaya khas Najwa Shihab yang sering dijumpai pada segmen pembuka dan penutup yang disampaikan dalam bentuk narasi pada acara Mata Najwa di Trans7. Penggunaan 
rima dalam tuturan Najwa Shihab tidak hanya bertujuan untuk memperoleh kesan estetis tetapi juga memberikan efek penekanan pada makna antar klausa dan kalimat.

(10) Lockdown di Manila bisa gambarkan ke kami situasinya seperti apa karena ada persepsi seolah-olah itu menjadi apa namanya momok, menyeramkan apakah memang seperti itu. (T3-GKha/5)

Pada data 10 terdapat kata seolah-olah. Kata seolah-olah mempunyai arti seperti atau seakan-akan. Kata seolah-olah yang digunakan Najwa Shihab bertujuan untuk membandingkan dua hal dan meminta tanggapan dari salah satu narasumber yaitu yang terjadi di Manila lockdown, apakah itu hanya persepsi atau hanya berita biasa. Dapat dikatakan kata seolah-olah merupakan gaya khas Najwa Shihab untuk membandingkan dua hal yang berbeda tetapi masih mempunyai segi yang serupa.

Dari jenis diksi dan gaya bahasa yang digunakan Najwa Shihab dalam menyampaikan pesan berupa verbal maka diperoleh beberapa fungsi dari retorika verbal berupa diksi dan gaya bahasa yang digunakan Najwa Shihab.

a. Membangun Watak atau Karakter Pemirsa

Hal ini dibuktikan dengan tuturan Najwa Shihab yang dapat membangun watak atau karakter pemirsa terdapat pada data: (T3-DDen/6)

Tuturan dari Najwa Shihab yang terdapat dalam data T3-DDen/6 bertujuan untuk menanamkan dan menciptakan watak baik kepada pemirsa bahwa boleh melakukan ibadah dirumah karena adanya suatu sebab yaitu semakin menyebarnya virus corona maka hal itu diperbolehkan melakukan ibadah dirumah, dan hal itu merupakan salah satu usulan dari MUI.

b. Mampu mengendalikan emosi pemirsa

Dari tuturan Najwa Shihab yang mampu dalam mengendalikan emosi narasumber terlihat pada data 12 (T1-DDen/2). Kalimat pada data tersebut memperlihatkan bahwa Najwa Shihab mampu dalam mengendalikan emosi narasumber, hal itu dibuktikan ketika Mbak Ninik memberi tanggapan dari apa yang sedang disampaikan oleh Pak Mueldoko, seketika Najwa Shihab juga memberikan tanggapan dari kedua narasumber tersebut.

c. Mampu menyodorkan bukti-bukti tentang suatu kebenaran 
Dari retorika verbal yang digunakan Najwa Shihab menunjukkan mampu menyodorkan bukti tentang suatu kebenaran terlihat pada data 8 (T1-DDen/1)

Pada data 8 dijelaskan bahwa dari retorika verbal yang digunakan Najwa Shihab mampu menggali informasi yang belum diketahui oleh publik yaitu Najwa Shihab memperoleh informasi yang akurat terkait dengan kesaksian pasien 01 .

\section{Strategi Retorika Nonverbal}

Menurut Larry A. Samovar dan Richard E. Porter, komunikasi nonverbal mencakup semua rangsangan kecuali rangsangan bentuk verbal dalam suatu setting komunikasi yang dihasilkan oleh individu dan penggunaan lingkungan oleh individu yang mempunyai nilai pesan potensial bagi pengirim atau penerima (Riswandi, 2009: 69-70). Secara sederhana unsur nonverbal adalah semua isyarat yang bukan berbentuk kata atau kalimat.

Sementara itu, unsur nonverbal yang terdapat dalam retorika merupakan suatu komponen sangat penting di dalam keseluruhan komunikasi, tetapi tidak dapat sepenuhnya itu dapat dipisahkan dari komponen lain. "Sedangkan elemen nonverbal dari bahasa tubuh meliputi wajah, kontak mata, sentuhan, suara, ekspresi wajah, penampilan fisik" (Hogan, 2010: 25).

Berikut ini pemakaian bahasa tubuh yang digunakan Najwa Shihab dalam acara Mata Najwa di Trans7 terdapat pada data 1, 2, 3,4 (Episode Melawan Corona).

(1) Memberikan ilustrasi tentang topik yang akan disampaikan dalam bentuk narasi dengan pandangan mata fokus ke depan kamera di iringi dengan gerakan tangan. (T1-Non/1)

Pada data 1 terdapat bahasa tubuh dari elemen " mata dan gerakan tangan " yang saling berkaitan ketika Najwa Shihab memberikan ilustrasi tentang topik yang akan disampaikan yaitu dalam bentuk narasi. Bahasa tubuh " pandangan mata " yang digunakan Najwa Shihab menunjukkan bahwa topik yang diangkat dalam diskusi sangat penting, sedangan di iringi " gerakan tangan " menunjukkan menyakinkan pendengar dari apa yang disampaikannya.

(2) Menyapa narasumber dan memperkenalkannya kepada publik dengan ekspresi wajah tersenyum dan pandangan mata tertuju kepada narasumber yang sedang disapa. (T1-Non/1) 
Pada data 2 Najwa Shihab menyapa narasumber dengan " ekspresi wajah tersenyum dan pandangan mata tertuju kepada narasumber yang sedang disapa " itu menunjukkan bahwa Najwa Shihab menghormati narasumber dan juga terima kasih sudah meluangkan waktunya untuk menghadiri undangan acara Mata Najwa di Trans7.

(3) Mendengar penjelasan dari narasumber dengan tangan memegang pena dan posisi badan agak serong ke arah narasumber yang sedang diwawancarai. (T1-Non/1).

Pada data 3 Najwa Shihab ketika mendengar penjelasan dari narasumber dengan " tangan memegang pena menggambarkan bahwa informasi yang telah didapat dari narasumber dicatat. Sedangkan "posisi badan agak serong" menggambarkan bahwa Najwa Shihab memerhatikan penjelasan ketika narasumber memberi informasi atau tanggapan.

(4) Bertanya tentang informasi yang dibahas pada narasumber yang sedang diwawancarainya dengan di iringi gerangan tangan. (T1-Non/1)

Pada data 4 terdapat bahasa tubuh "gerakan tangan" menunjukkan bahwa dari gerakan tangan tersebut menyakinkan narasumber dari yang ditanyakan oleh Najwa Shihab.

Dari gerak tubuh atau nonverbal yang digunakan Najwa Shihab maka peneliti memperoleh beberapa fungsi dari retorika nonverbal yang digunakan Najwa Shihab dalam acara Mata Najwa di Trans7.

a. Menarik Perhatian

Seni retorika yang dimiliki Najwa Shihab memang sangat memukau dan mengesankan, dari diksi dan gaya bahasa yang digunakan dapat memengaruhi pemirsa. Dari tuturan Najwa Shihab yang membuktikan dapat menarik perhatian pemirsa terdapat pada data 14 (T1-DDen/3)

Pada data 14 menggambarkan informasi yang diperoleh Najwa Shihab tentang kesiapan rumah sakit RSCM dapat menarik perhatian pemirsa salah satunya dapat dijadikan sebagai sumber informasi bagi yang terpapar virus corona.

b. Memperkuat retorika verbal 
Dalam tuturan Najwa Shihab yang merupakan salah satu fungsi retorika nonverbal bagian memperkuat retorika verbal terdapat pada data 1 (T1-Non/1)

Memberikan ilustrasi tentang topik yang akan disampaikan dalam bentuk narasi dengan pandangan mata fokus ke depan kamera di iringi dengan gerakan tangan.

\section{c. Pencitraan diri}

Melalui sikap Najwa Shihab yang mencari tahu tentang informasi hotline penanganan virus corona menunjukkan citra diri yang peduli, iba terhadap peristiwa yang terjadi pada salah satu narasumber.

d. Bentuk penghargaan terhadap pemirsa. Setiap kali selesai narasumber memberikan informasi yang terkait, Najwa Shihab memberikan simpulan dari yang disampaikan narasumbernya.

Strategi pembawa acara dalam sebuah acara merupakan kunci suksesnya suatu acara. Pemakaian retorika verbal dan nonverbal dalam strategi pembawa acara sangat membantu strategi yang digunakan pembawa acara. Dari jenis diksi dan gaya bahasa yang digunakan Najwa Shihab maka peneliti menemukan adanya kaitan retorika verbal dan nonverbal dalam strategi yang digunakan pembawa acara banyak mengandung unsur persuasi, diantaranya dari tuturan Najwa Shihab yang mengandung diksi dan gaya bahasa dapat menciptakan karakter atau watak pemirsa, hal ini dibuktikan peneliti lewat data yang telah dicari dan dianalisis terkait dengan retorika verbal dan nonverbal.

Menjadi seorang pembicara di depan umum harus mampu menimbulkan kepercayaan terhadap audiensnya, memiliki watak yang baik, serta memiliki kemampuan berfikir secara teratur. Selanjutnya, dari diksi dan gaya bahasa yang dipilih Najwa Shihab juga mampu dalam mengendalikan emosi pemirsa, hal itupun sudah terbukti data yang diperoleh dari tuturan Najwa Shihab, Kemantapannya dalam berbicara keteraturan proses berfikirnya dan bahasa yang digunakan semua akan mencerminkan latar belakangnya. Dari tuturan Najwa Shihab selain dapat menciptakan watak atau karakter pemirsa, juga mampu mengendalikan emosi pemirsa, Najwa Shihab juga mampu mempertanggungjawabkan dari tuturannya itu dengan menyodorkan bukti-bukti yang akan memperkuat informasi yang didapatkannya. 
Terkait dengan retorika nonverbal atau bahasa tubuh yang digunakan Najwa Shihab digunakan sebagai proses untuk melancarkan strategi pembawa acara Mata Najwa di Trans7. Dari data yang diperoleh retorika nonverbal yang digunakan Najwa Shihab berhasil menarik perhatian audiens, retorika nonverbal menjadi penguat dari retorika verbal, pencitraan diri dan bentuk penghargaan terhadap pemirsa, hal itu yang menjadi fungsi dari retorika nonverbal yang digunakan Najwa Shihab dalam gelar wicara Mata Najwa di Trans7.

\section{Kesimpulan}

Berdasarkan hasil penelitian dapat disimpulkan bahwa penggunaan retorika verbal dan nonverbal dalam kaitan strategi pembawa acara dalam gelar wicara Mata Najwa di Trans7. Dari diksi berupa denotatif dan konotatif serta gaya bahasa yang digunakan Najwa Shihab semuanya mempunyai strategi diksi dan gaya bahasa yang dapat mempengaruhi pendengar. Serta berbagai elemen nonverbal (bahasa tubuh) berfungsi untuk melancarkan proses strategi pembawa acara dalam memengaruhi pendengar. Dari semua elemen verbal dan nonverbal yang dipilih dalam gelar wicara Mata Najwa banyak mengandung unsur persuasi, yaitu mampu membangun watak atau karakter, mampu mengendalikan emosi pemirsa, menarik perhatian, meyakinkan, serta pertanyaan-pertanyaan yang terarah dan tajam, kemampuan dalam mengalihkan narasumber, semua dari karakteristik retorika verbal dan nonverbal itu digunakan sebagai strategi pembawa acara dalam memengaruhi pendengar yang menyaksikan gelar wicara Mata Najwa di Trans7.

\section{DAFTAR PUSTAKA}

Aristoteles. (2018). Retorika seni berbicara. Yogyakarta: Basabasi.

Cangara, Hafied. 2011. Pengantar Ilmu Komunikasi. Jakarta: PT Raja Grafindo Persada.

Depari, Rien Arman. 2014. Sukses Menjadi Pembawa Acara. CV Tiga Abang. Keraf, Gorys. 2016. Diksi dan Gaya Bahasa. Jakarta: PT Ikrar Mandiriabadi. Keraf, Gorys. 2007. Argumentasi dan Narasi. Jakarta: PT Gramedia Pustaka Utama. 
Mahsun. 2017. Metode Penelitian Bahasa. Depok: PT Raja Grafindo Persada. Ali Manshur, F. Z. I. (2021). Senyapan dan Kilir Lidah dalam Acara Gelar Wicara Mata Najwa 2020 sebagai Kajian Psikolinguistik. PENEROKA, 1(01), 2441.

Hikmah, S. N. A. H. (2021). Problematika Pencapaian Kompetensi Keterampilan Berbicara Siswa dalam Pembelajaran Bahasa Indonesia. PENEROKA, 1(01), $59-67$.

Rakhmat, Jalaluddin. 2009. Retorika Modern. Bandung: PT Remaja Rosdakarya. Ningsih, Asti. 2018. Bicara Itu Ada Seninya. Jakarta : Bhuana Ilmu Populer.

Sugiyono. 2016. Metode Penelitian: kuantitaf, kualitatif, dan R\&D. Bandung: Alfabeta.

Sugiyono. 2015. Metode Penelitian Pendidikan: Pendekatan Kuantitatif, Kualitatif, dan R\&D.

Suranto Aw. 2011. Komunikasi Interpersonal. Yogyakarta: Graha Ilmu.

Zuhri, Saifuddin. 2010. Publik Speaking. Yogyakarta: Graha Ilmu.

Syahrul, Tressyalina, dan Farel. 2017. Metodologi Penelitian Pembelajaran Bahasa Indonesia. Padang: SUKABINA Press.

Dewi, Fitriana Utami. 2013. Public Speaking (Kunci Sukses Bicara di depan Publik) Yogyakarta: Pustaka Belajar. 